peptide moiety of the polysaccharide could be composed of the so-called 'cell wall peptide'. 'The presence of $\alpha \varepsilon$-diaminopimelic acid and unidentified aminosugar in the polysaccharide suggest that the cell wall of $B$. anthracis consists - in part at least-of a compound of the polysaccharide and the 'cell wall pep. tide'. In this connexion it is recalled that a preparation from Bacillus ' $M$ ' described by Guex-Holzer and Tomcsik $^{\theta}$ contained $\alpha \varepsilon$-diaminopimelic acid, unidentified amino-sugar, galactose and glucosamine as well as large quantities of phosphorus, although rigorous tests for homogeneity of the preparation were not described.

H. SMITH

R. E. Strange

H. T. ZWARTOUW

Ministry of Supply,

Microbiological Research Establishment, Porton, Wilts. June 11.

${ }^{1}$ Tomesik, J., Symp. Soc. Gen. Microbiol., 6 ,Bacterial Anatomy, 41 (1956).

${ }^{2}$ Ivanovics, G., Z. Immun. Forsch., 97, 402 (1940).

${ }^{3}$ Strange, R. E., and Belton, F. C., Brit. J. Exp. Path., 35, 153 (1954).

${ }^{4}$ Smith, H., and Zwartouw, H. T., Biochem. J., 63, 447 (1956).

${ }^{5}$ Cummins, C. S., and Harris, H., Biochem. J., 57, 32 (1955); J. Gen. Microbiol., 13, 3 (1955).

${ }^{B}$ Strange, R. E., and Powell, J. F., Biochem. J., 58, 80 (1954).

${ }^{7}$ Rhuland, L. E., Work, E., Denham, R. F., and Hoare, D. S., J. Amer. Chem. Soc., 'y7, 4844 (1955).

${ }^{8}$ Strange, R. F., and Dark, F. A., Nature, 177, 186 (1956).

Guex-Holzer, S., and Tomesik, J., J. Gen. Microbiol., 14, 14 (1956).

\section{A Pasture Response to Sodium Tungstate on a New Zealand Soil}

IN an investigation of an apparent superiority of basic slag over superphosphate in stimulating pasture growth on a yellow-grey earth of the Warepa series (Otago Province), slag-treated plots were compared in 1951 with plots receiving superphosphate, (1) alone, (2) plus $\frac{1}{8}$ oz. sodium molybdate, (3) plus $2 \frac{1}{2} \mathrm{oz}$. molybdate and (4) plus 1 lb. ammonium metavanadate per acre. Molybdenum application at both rates markedly increased pasture production, notably through the clovers, while vanadium had no effect. In September 1953 sodium tungstate (molybdenum content $<0 \cdot 1$ p.p.m.) was applied over one block of the experiment at $1 \mathrm{lb}$./acre. 'The superphosphate plot with no applied molybdenum and that with vanadium responded greatly, particularly in white clover growth, that with $\frac{1}{8} \mathrm{oz}$. sodium molybdate responded slightly, while the plot treated with the heavier rate of sodium molybdate showed no addi. tional effect from tungsten ${ }^{1}$. The implication was that tungsten could assume the role of molybdenum, presumably in nitrogen fixation by Rhizobia. A replicated trial studying the interactions of molyb. denum, tungsten and vanadium, applied in proportion to their atomic weights (sodium molybdate $2 \frac{1}{2} \mathrm{oz}$./acre), has now been run on the same soil type. The trial was laid down on March 24, 1955. In the five yield cuts so far taken covering the period August 10, 1955-February 28, 1956, vanadium has had no influence either by itself or in conjunction with molybdenum or tungsten. It can therefore be disregarded in considering the molybdenum $\times$ tungsten interaction. Results are exemplified by data from the second yield cut in the tungsten $\times$ molybdenum interaction table (Table 1).
Table 1. YintDS OF DRY MATTER LB./ACRE, OCTOBER 13-NOVEMBER 10. Table 1. YIMLDS OF DRY MATIER LB.

\begin{tabular}{|l|c|c|c|}
\hline & No tungsten & Tungsten & Mean \\
\hline $\begin{array}{l}\text { No molybdenum } \\
\text { Molybdenum }\end{array}$ & 770 & 940 & 850 \\
Mean & 940 & 1,070 & 1,100 \\
\hline
\end{tabular}

Sig. diff.: 5 per cent, $100 ; 1$ per cent, 130 .
Molybdenum $\times$ tungsten interaction significant at 1 per cent level.

There is a significant response to tungsten only in the absence of molybdenum. In the presence of tungsten in the above cut, response to molybdenum just achieves significance at the 1 per cent level. Two further yield cuts gave similar results while the interaction in the first and fourth was not significant. Over the whole period of $6 \frac{1}{2}$ months both molybdenum alone and molybdenum plus tungsten gave a 27 per cent increase in dry matter production; tungsten in the absence of molybdenum a 16 per cent increase.

In an accompanying trial, rates of sodium tungstate at $1,2,4,8$ and $16 \mathrm{oz}$. per acre were compared. By the third cut all rates were giving significant increases in yield of pasture, amounts above $4 \mathrm{oz}$./acre conferring no extra advantage. In the fifth cut yields were recorded increasing up to, but not beyond, the 8-oz. level.

Tungsten is probably acting as a substitute for molybdenum in its role in nitrogen fixation, but less effectively. Heavier applications, at least initially, have shown no advantage ; if tungstate merely freed soil molybdate held in an unavailable form one would have expected the reverse to hold. Moreover, the anion exchange effect of the far heavier basal application of phosphate $(2 \times 3$ cwt. superphosphate $)$ would have tended to mask any such action.

Bortels has directed attention to tungsten and vanadium having an effect similar to, but much smaller than, molybdenum in stimulating nitrogen fixation by blue-green algæ of the genera Anabaena and Nostoc ${ }^{2}$. In Bortels's studies with Azotobacter spp. and Clostridium butyricum ${ }^{3}$ tungsten increased effects of vanadium and, to some extent, of sub-optimal amounts of molybdenum, the former observation prompting the trial of tungsten in the present instance.

Rukuhia Soil Research Station, E. B. Davies

Hamilton, New Zealand.

S. M. J. STOCKDILL

Department of Agriculture,

Dunedin, New Zealand. Aug. 9.

1 Davies, E. B., and Grigg, J. L., Proc. N.Z. Soc. Anim. Prod., 15, 86 (1955).

${ }^{2}$ Bortels, H., Arch. Microbiol., 11, 155 (1940).

s Bortels, H., Z. Bakt. Parasitenk II, 95, 193 (1936).

\section{Phosphine as a Phosphatic Fertilizer}

SINCE ammonia gas has been highly satisfactory as a nitrogenous fertilizer it is surprising that there is no record of any experimental work on its analogue phosphine as a source of plant phosphorus. Phosphine has many obvious disadvantages; but the fact that it is more than ten times as concentrated as superphosphate, our standard arable phosphatic fertilizer, surely merits some consideration. Commercial handling may not present any more serious problems than did some of the modern phosphorus insecticides. 